\title{
A Systematic Review of the Factors Affecting the Growth of Medical Tourism in Iran
}

\author{
Maryam Gholami ${ }^{1}$, Ali Mohammad Keshtvarz Hesam Abadi ${ }^{*}$, Shima Milady², Marjan Gholami ${ }^{1}$ \\ ${ }^{1}$ Clinical Research Development Center, Shiraz University of Medical Sciences, Nemazee Hospital, Shiraz, Iran \\ Corresponding Author: Ali Mohammad Keshtvarz Hesam Abadi, MSc in Biostatistics, Clinical Research Development \\ Center, Shiraz University of Medical Sciences, Nemazee Hospital, Shiraz, Iran. Tel: +98-71-36474278, Email: \\ Alimohammad.keshtvarz@gmail.com
}

Received October 4, 2019; Accepted February 24, 2020; Online Published March 10, 2020

\begin{abstract}
Introduction: Planning in the field of medical tourism is of particular importance. The main objective of this research was to identify and analyze the factors affecting the growth of medical tourism in Iran. It could be a small step toward promoting entrepreneurship and increasing non-oil revenues in the country.

Methods: Studies published in the Persian and English language during the years 2006-2019 in Science Direct, ProQuest, Springer, Medline, Scopus, Ovid, and SID databases were reviewed, and the findings were then compared.

Results: A total of 75 articles out of 2631 unique publications were included in this study. Most articles reported studies performed for all patients, including the whole country $(\operatorname{Iran})(n=22,30 \%)$, Shiraz only $(n=11,15 \%)$, Tehran only $(n=11,15 \%)$, Mashhad only $(n=6,8 \%)$, Isfahan only $(n=5,6 \%)$, and Ardabil only $(n=4,5 \%)$.

Conclusion: Given the history of Iranian hospitals in attracting foreign patients and the analysis of their status, there are many limitations in achieving a proper standing in the medical tourism industry. Strategies offered by various managers and authorities in tourism can lead to increased attraction of medical tourists to public and private hospitals in Shiraz, relying on the capabilities and potential of Shiraz and its health sectors, including climate and nature, cultural and historical attractions, renowned practitioners, advanced equipment, facilities, and methods, and thereby generating more foreign exchange earnings and employment.

Keywords: Medical Tourism, Hospitals, Growth and Development, Iran
\end{abstract}

Citation: Gholami M, Keshtvarz Hesam Abadi AM, Milady S, Gholami M. A systematic review of the factors affecting the growth of medical tourism in Iran. Int J Travel Med Glob Health. 2020;8(1):1-12. doi:10.34172/ijtmgh.2020.01.

\section{Introduction}

According to the definition of the United Nations World Tourism Organization (UNWTO), a tourist refers to a person who travels and stays away from his or her usual environment for more than 24 hours and less than one year for various purposes, including recreation, rest, or business. ${ }^{1}$ Another reason for tourists is the search for healthcare that is known as a branch of tourism and has a long history. ${ }^{2}$ In its broadest conceptualization, medical tourism refers to "travel with the explicit purpose of obtaining health services abroad". ${ }^{3}$ Medical tourism today is one of the most important indicators of the tourism industry and has many socio-economic benefits. The integration of medical tourism with consumer health guidance programs is potentially a pivot for accelerating the development of medical tourism and economic development. ${ }^{4,5}$ Medical tourism has experienced remarkable growth in the last two decades. ${ }^{6,7}$ Various studies have suggested that the main reasons for this development are as follows: increasing waiting lists in advanced countries, ${ }^{8-11}$ increasing international exchange rates, the Internet (With the development of the communications network, new companies have been formed as the interface between international patients and the hospital network, which provides basic information to the patients.), the low cost of services in developing countries, ${ }^{11-14}$ and modern technologies and equipment that fit into new health services. ${ }^{15}$ In Iran's fourth development plan of Article 87 , the ground for effective participation in world markets and the transformation of the Islamic Republic of Iran into a center for addressing the health and medical needs of the region has been emphasized. Considering the fact that Iran has neighboring countries that have lower therapeutic and medical standards, with the help of experienced medical staff and competent therapeutic centers, Iran can be one of the best destinations for medical tourists.

It is estimated that the income of every case of medical tourism is three times that of a typical tourist. ${ }^{16}$ In 2012, 3.3

Copyright $(\subset) 2020$ The Author(s). This is an open-access article distributed under the terms of the Creative Commons Attribution License (http:// creativecommons.org/licenses/by/4.0), which permits unrestricted use, distribution, and reproduction in any medium, provided the original work is properly cited. 
million tourists entered the country, and 687500 people were employed in the industry. ${ }^{17}$ Therefore, planning based on the priorities specified in the field of medical tourism are very important. The main objective of this research was to identify and analyze the factors affecting the growth of medical tourism in Iran.

\section{Methods}

\section{Search Strategy}

In this systematic review study, studies published in the Persian and English languages during the years 2006-2019 in the databases of Science Direct, ProQuest, Springer, Medline, Scopus, Ovid, and SID were reviewed, and the findings were then compared. Keywords for the search included tourism, medical tourism, and health tourism, specifically in Iran. The text of the reviewed articles and their results were extracted by the researchers. Finally, the results of the studies were summarized and reported.

\section{Article Selection}

The inclusion criteria for the present study were: 1 . use of the keywords designated for the title and abstracts of articles, 2. completed research, 3. research conducted on the subject of Iran, 4. English or Persian language articles, 5. use of quantitative and qualitative research methods, and 6. Including factors or programs on the topic of tourism in the field of health. The exclusion criteria included: 1. abstracts only, 2. studies published in other countries despite having an Iranian author, and 3. studies published in other languages that were unfamiliar to the researchers. Duplicate studies were also excluded. Studies that met the inclusion criteria were coded and compared.

Figure 1 displays the process of the study selection. Overall, the literature search identified 2191 records of databases. After excluding duplicate articles and articles with unrelated topics, 470 records remained. Based on a review of the abstracts, 182 articles remained. A total of 107 articles were excluded due to the lack of stating the factor and development plan. Ultimately, 75 articles were entered into the current study.

\section{Results}

The characteristics of the articles are summarized in Table 1. Most articles were original research studies ( $n=61,81 \%)$; nonoriginal research articles $(\mathrm{n}=14,19 \%)$ consisted of reviews $(n=7,9.5 \%)$ and case studies $(n=7,9.5 \%)$. Most articles reported studies performed on all patients including the whole country (Iran) $(n=22,30 \%)$, Shiraz only $(n=11,15 \%)$, Tehran only $(n=11,15 \%)$, Mashhad only $(n=6,8 \%)$, Isfahan only $(n=5,6 \%)$, and Ardabil only $(n=4,5 \%)$.

Seven papers written between 2008 and 2011, 26 papers written between 2012 and 2014, and 41 articles written between 2015 to 2018 indicated that more attention has been paid to medical tourism in Iran in recent years. Eighteen articles cited cost factor and 11 articles cited medical equipment

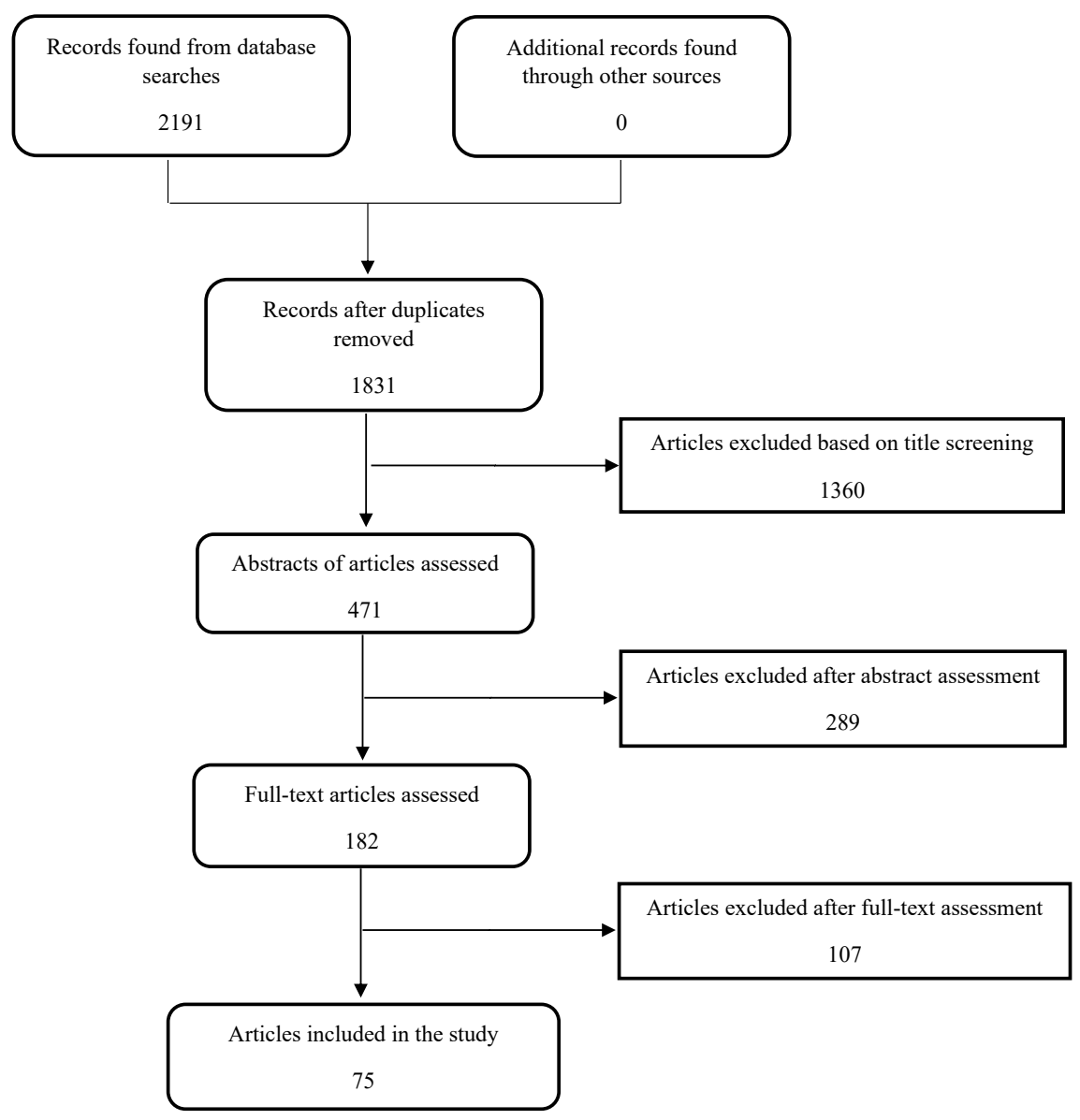

Figure 1. Flow Chart of the Article Selection Process. 
Table 1. Details of Articles Included in the Review

\begin{tabular}{|c|c|c|c|c|c|c|}
\hline \multirow{2}{*}{ Author } & \multirow{2}{*}{ Year } & \multirow{2}{*}{ Type of Research } & \multirow{2}{*}{$\begin{array}{l}\text { Place of } \\
\text { research }\end{array}$} & \multicolumn{3}{|c|}{ The Most Important Factors, Suggestions, and Programs for the Development of Medical Tourism in Iran } \\
\hline & & & & Factors & Suggestions & Programs \\
\hline Kazemi et al ${ }^{18}$ & 2008 & $\begin{array}{l}\text { Descriptive- } \\
\text { survey }\end{array}$ & $\begin{array}{l}\text { Whole country } \\
\text { (Iran) }\end{array}$ & $\begin{array}{l}\text { The proper functions of responsible organizations; the special } \\
\text { geographical location of Iran, being as an Islamic country }\end{array}$ & - & - \\
\hline $\begin{array}{l}\text { Zia } \\
\text { Sheikholeslami } \\
\text { et al }{ }^{19}\end{array}$ & 2010 & Descriptive & Rafsanjan & - & - & $\begin{array}{l}\text { Enhance the English language among medical staff; increase } \\
\text { investment; establish medical tourism clinics in the vicinity } \\
\text { of hot springs. }\end{array}$ \\
\hline Tourani et a $2^{20}$ & 2010 & $\begin{array}{l}\text { Cross-sectional } \\
\text { survey }\end{array}$ & $\begin{array}{l}\text { Whole country } \\
\text { (Iran) }\end{array}$ & - & - & $\begin{array}{l}\text { The government should encourage and support the private } \\
\text { sector to act in all areas of this industry from participating } \\
\text { in policy-making and strategic planning to marketing and } \\
\text { introducing Iran's health services to target countries, act as } \\
\text { medical tourism facilitators, and provide health and medical } \\
\text { services. }\end{array}$ \\
\hline Jafary et $\mathrm{a}^{21}$ & 2011 & Review & $\begin{array}{l}\text { Whole country } \\
\text { (Iran) }\end{array}$ & - & - & $\begin{array}{l}\text { The presence of accredited foreign media and reporting } \\
\text { on the capabilities of the country's medical community; } \\
\text { providing the facilities, equipment, and services needed by } \\
\text { this group of tourists. }\end{array}$ \\
\hline $\begin{array}{l}\text { Moghimehfar } \\
\text { et al }{ }^{22}\end{array}$ & 2011 & $\begin{array}{l}\text { Descriptive- } \\
\text { survey }\end{array}$ & Isfahan & Legal, moral, and religious restrictions & $\begin{array}{l}\text { Providing an appropriate environment } \\
\text { where infertile couples' religious beliefs } \\
\text { are respected and considered during the } \\
\text { treatment of infertility through ART }\end{array}$ & - \\
\hline Khodayari et al ${ }^{23}$ & 2011 & $\begin{array}{l}\text { Cross-sectional } \\
\text { survey }\end{array}$ & Tehran & $\begin{array}{l}\text { Access to and continuity of treatment, patient evaluation, anesthesia and } \\
\text { drug management, patient and family rights, patient care, and patient } \\
\text { education }\end{array}$ & - & - \\
\hline Nasiripour et a ${ }^{24}$ & 2011 & $\begin{array}{l}\text { Cross-sectional } \\
\text { survey }\end{array}$ & Tehran & $\begin{array}{l}\text { Medical equipment, information and communication technology, more } \\
\text { competitive pricing of medical services than other countries, and clearing } \\
\text { the cost of foreign patients' requests. }\end{array}$ & - & - \\
\hline $\begin{array}{l}\text { Sadr Momtaz } \\
\text { et al }{ }^{25}\end{array}$ & 2011 & $\begin{array}{l}\text { Cross-sectional } \\
\text { survey }\end{array}$ & Tehran & - & $\begin{array}{l}\text { Public infrastructure development strategy; } \\
\text { Human resources development strategy; } \\
\text { Information and Marketing System } \\
\text { Development Strategy; } \\
\text { Product Development Strategy }\end{array}$ & - \\
\hline Izadi et a| ${ }^{26}$ & 2012 & $\begin{array}{l}\text { Descriptive } \\
\text { review }\end{array}$ & $\begin{array}{l}\text { Whole country } \\
\text { (Iran) }\end{array}$ & $\begin{array}{l}\text { Expert physicians, up-to-date medical technology, natural healing regions } \\
\text { to attract health tourists }\end{array}$ & $\begin{array}{l}\text { Comprehensive planning and operational } \\
\text { requirements of field units and provide } \\
\text { leadership }\end{array}$ & - \\
\hline Ferdosi et $\mathrm{a}^{27}$ & 2012 & $\begin{array}{l}\text { Review and } \\
\text { qualitative }\end{array}$ & - & - & - & Conducting accurate and comprehensive research in Iran \\
\hline
\end{tabular}


Table 1. Continued

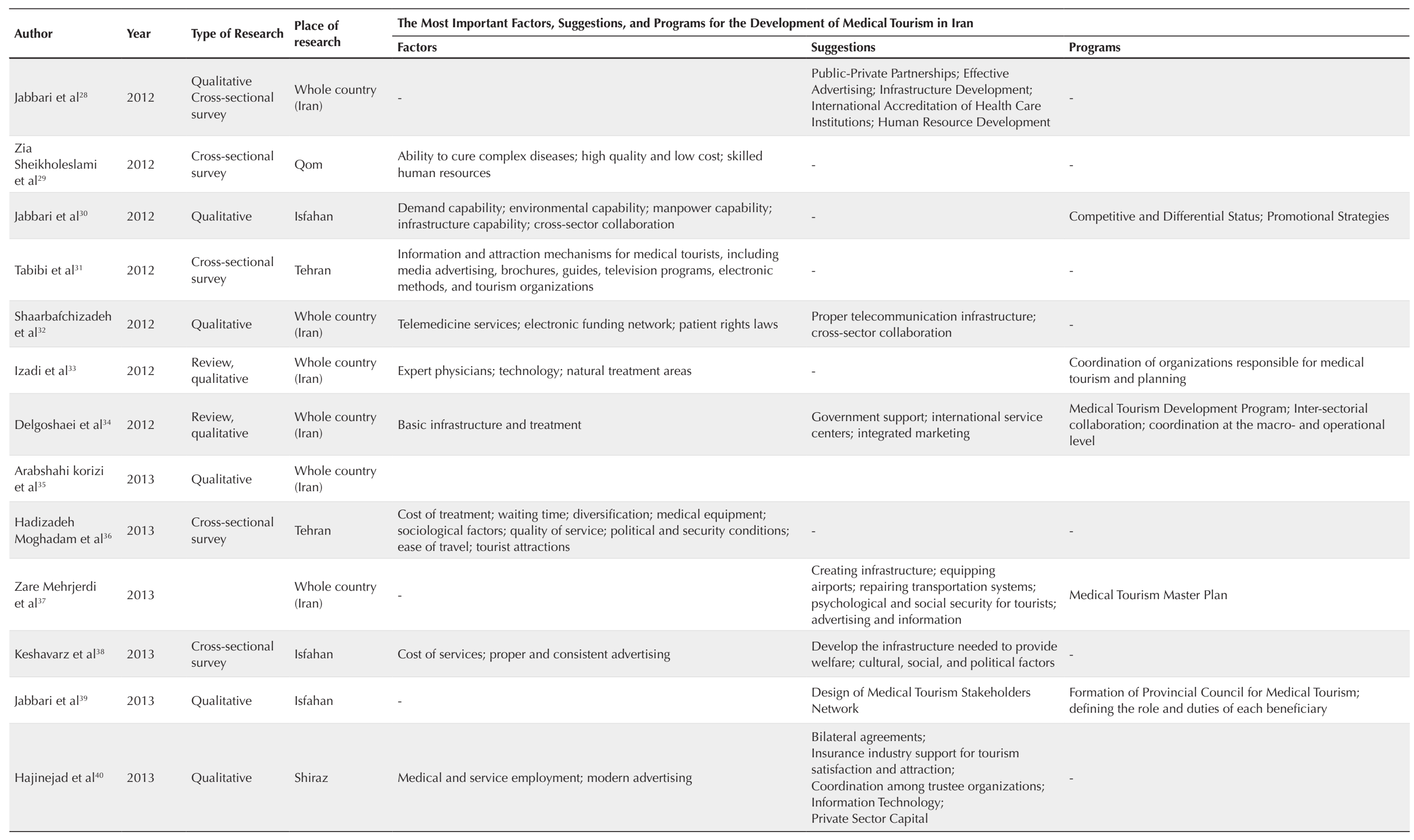


Table 1. Continued

\begin{tabular}{|c|c|c|c|c|c|c|}
\hline \multirow{2}{*}{ Author } & \multirow{2}{*}{ Year } & \multirow{2}{*}{ Type of Research } & \multirow{2}{*}{$\begin{array}{l}\text { Place of } \\
\text { research }\end{array}$} & \multicolumn{3}{|c|}{ The Most Important Factors, Suggestions, and Programs for the Development of Medical Tourism in Iran } \\
\hline & & & & Factors & Suggestions & Programs \\
\hline Rokni et al ${ }^{41}$ & 2013 & $\begin{array}{l}\text { Cross-sectional } \\
\text { survey }\end{array}$ & Shiraz & - & $\begin{array}{l}\text { Cooperation with countries in the region; } \\
\text { Religious and cultural proximity; Effective } \\
\text { advertising; Periodic evaluations }\end{array}$ & - \\
\hline Mahdavi et a $\mathrm{a}^{42}$ & 2013 & $\begin{array}{l}\text { Review } \\
\text { qualitative }\end{array}$ & $\begin{array}{l}\text { Whole country } \\
\text { (Iran) }\end{array}$ & - & $\begin{array}{l}\text { Branding; coordination between } \\
\text { stakeholders; provision of coherent services }\end{array}$ & - \\
\hline Jabbari et al ${ }^{43}$ & 2013 & $\begin{array}{l}\text { Cross-sectional } \\
\text { survey }\end{array}$ & Shiraz & - & $\begin{array}{l}\text { Effective advertising; } \\
\text { Infrastructure development; } \\
\text { Quality management systems }\end{array}$ & Medical tourism strategic plan \\
\hline $\begin{array}{l}\text { Tabatabaeei nasab } \\
\text { et al }{ }^{44}\end{array}$ & 2014 & $\begin{array}{l}\text { Descriptive- } \\
\text { survey }\end{array}$ & Yazd & Experienced medical staff; environmental status; cost & - & Increasing marketing for medical tourism \\
\hline Mesbahi et al ${ }^{45}$ & 2014 & Qualitative & $\begin{array}{l}\text { Whole country } \\
\text { (Iran) }\end{array}$ & - & $\begin{array}{l}\text { Using web information systems to introduce } \\
\text { service providers; building a relationship } \\
\text { between service provider and customer }\end{array}$ & - \\
\hline Goodarzi et al ${ }^{46}$ & 2014 & Qualitative & Shiraz & $\begin{array}{l}\text { Price of treatment and tourist services; quality of treatment and tourist } \\
\text { services; treatment and tourist facilities; capabilities and equipment; ICT } \\
\text { and culture }\end{array}$ & - & $\begin{array}{l}\text { The high quality of treatment and tourist services; applying } \\
\text { capabilities and modern equipment compatible with } \\
\text { universal standards in treatment and tourist domain; applying } \\
\text { ICT in advertising and marketing; promoting the culture of } \\
\text { accepting tourism }\end{array}$ \\
\hline Goodarzi et al ${ }^{48}$ & 2014 & $\begin{array}{l}\text { Cross-sectional } \\
\text { survey }\end{array}$ & Shiraz & $\begin{array}{l}\text { Price transparency of health services; quality of health services; facilities; } \\
\text { ICT }\end{array}$ & - & - \\
\hline Goodarzi et al ${ }^{49}$ & 2014 & $\begin{array}{l}\text { Cross-sectional } \\
\text { survey }\end{array}$ & Shiraz & Quality of service; culture; facilities; price; ICT & - & - \\
\hline Mir et al ${ }^{50}$ & 2014 & $\begin{array}{l}\text { Cross-sectional } \\
\text { survey }\end{array}$ & Zahedan & $\begin{array}{l}\text { High-quality new equipment; recreational and tourist attractions; } \\
\text { specialized manpower; patient welfare facilities }\end{array}$ & - & - \\
\hline Ayoubian et a $\left.\right|^{51}$ & 2014 & $\begin{array}{l}\text { Cross-sectional } \\
\text { survey }\end{array}$ & Tehran & Quality and cost of service & $\begin{array}{l}\text { Media advertisements; descriptions of } \\
\text { equipment and manpower capabilities }\end{array}$ & Coherent policymaking \\
\hline $\begin{array}{l}\text { Taj Zadeh namen } \\
\text { et al }\left.\right|^{52}\end{array}$ & 2015 & $\begin{array}{l}\text { Descriptive- } \\
\text { survey }\end{array}$ & Tehran & $\begin{array}{l}\text { Validity of information; characteristics of treatment centers; website } \\
\text { specifications; transparency in information; advertising policies }\end{array}$ & - & - \\
\hline Safaeepur et al ${ }^{53}$ & 2015 & $\begin{array}{l}\text { Cross-sectional } \\
\text { survey }\end{array}$ & $\begin{array}{l}\text { Whole country } \\
\text { (Iran) }\end{array}$ & - & $\begin{array}{l}\text { Variety of specialized services, public and } \\
\text { private sector coordination }\end{array}$ & $\begin{array}{l}\text { Strategies to reduce costs and increase quality in comparison } \\
\text { with countries in the region, } \\
\text { Coherent decision-making and service delivery system }\end{array}$ \\
\hline Hosseini et al ${ }^{54}$ & 2016 & $\begin{array}{l}\text { Descriptive- } \\
\text { survey }\end{array}$ & Tehran & Therapeutic care and facilities; clarity of medical costs & - & - \\
\hline Karami et al ${ }^{55}$ & 2016 & $\begin{array}{l}\text { Descriptive- } \\
\text { survey }\end{array}$ & Mashhad & $\begin{array}{l}\text { Advanced medical facilities and equipment; the skill and expertise of } \\
\text { medical staff; religious beliefs and opinions }\end{array}$ & - & - \\
\hline
\end{tabular}




\section{Table 1. Continued}

\begin{tabular}{|c|c|c|c|c|c|c|}
\hline \multirow{2}{*}{ Author } & \multirow{2}{*}{ Year } & \multirow{2}{*}{ Type of Research } & \multirow{2}{*}{$\begin{array}{l}\text { Place of } \\
\text { research }\end{array}$} & \multicolumn{3}{|c|}{ The Most Important Factors, Suggestions, and Programs for the Development of Medical Tourism in Iran } \\
\hline & & & & Factors & Suggestions & Programs \\
\hline Lajevardi et al ${ }^{56}$ & 2016 & $\begin{array}{l}\text { Descriptive- } \\
\text { survey }\end{array}$ & $\begin{array}{l}\text { Whole country } \\
\text { (Iran) }\end{array}$ & Motivational factor; destination image & - & - \\
\hline $\begin{array}{l}\text { Mahmoudifar } \\
\text { et a }\left.\right|^{57}\end{array}$ & 2016 & $\begin{array}{l}\text { Descriptive- } \\
\text { analytical }\end{array}$ & West Azerbaijan & $\begin{array}{l}\text { Public infrastructure; general conditions to attract tourists; legal terms; } \\
\text { political conditions; economic conditions; cultural conditions }\end{array}$ & $\begin{array}{l}\text { Attention to elements such as the appropriate } \\
\text { conditions to attract medical tourism based } \\
\text { on political, legal, and regional economic } \\
\text { development. }\end{array}$ & - \\
\hline Bishami et al ${ }^{58}$ & 2016 & $\begin{array}{l}\text { Descriptive- } \\
\text { survey }\end{array}$ & Tabriz & Famous doctors, equipment and facilities, cost & Creating an extensive network of marketing & Enhance the English language among medical staff \\
\hline Nemati et al ${ }^{59}$ & 2016 & Survey & Ardabil & $\begin{array}{l}\text { Barriers to information systems and marketing; infrastructural barriers; } \\
\text { barriers to product development and quality of service; administration's } \\
\text { attitude barriers; barriers of manpower; socio-cultural barriers; economic } \\
\text { barriers }\end{array}$ & - & $\begin{array}{l}\text { Use of domestic and foreign media to promote medical } \\
\text { tourism capabilities; Attracting investment and initiatives to } \\
\text { develop and increase the capacity of hospitals }\end{array}$ \\
\hline Ranjnoosh et al ${ }^{60}$ & 2016 & $\begin{array}{l}\text { Descriptive- } \\
\text { survey }\end{array}$ & $\begin{array}{l}\text { Whole country } \\
\text { (Iran) }\end{array}$ & - & $\begin{array}{l}\text { Development of medical centers based } \\
\text { on international standards; Improving } \\
\text { Human Resource Communication Skills; } \\
\text { Implementation of integrated and systematic } \\
\text { management of service delivery }\end{array}$ & - \\
\hline Mirbolouk et a $\left.\right|^{61}$ & 2016 & $\begin{array}{l}\text { Descriptive- } \\
\text { survey }\end{array}$ & Guilan & $\begin{array}{l}\text { Perceived medical quality; perceived service quality; perceived } \\
\text { reputation; religion }\end{array}$ & $\begin{array}{l}\text { Improving medical infrastructure; increasing } \\
\text { medical and tourism quality; providing } \\
\text { correct and comprehensive facilities for } \\
\text { patients and their companions }\end{array}$ & - \\
\hline Samadbeik et al ${ }^{62}$ & 2016 & Qualitative & Shiraz & - & - & Designing proper medical tourism websites for hospitals \\
\hline $\begin{array}{l}\text { Taghi Zadeh Yazdi } \\
\text { et al }{ }^{63}\end{array}$ & 2016 & Content analysis & - & $\begin{array}{l}\text { Medical tourism facilitation websites; contents introducing medical } \\
\text { options; introducing website facilities; introducing medical tourism; } \\
\text { introducing website; patient and audience comments }\end{array}$ & - & - \\
\hline Badiei et al ${ }^{64}$ & 2016 & Qualitative & Golestan & - & $\begin{array}{l}\text { Increasing private participation; establishing } \\
\text { hospitals and clinics }\end{array}$ & Public sector participation; support from the private sector \\
\hline $\begin{array}{l}\text { Hamidizadeh } \\
\text { et al }{ }^{65}\end{array}$ & 2016 & Case study & $\begin{array}{l}\text { Tehran, } \\
\text { Mashhad, Shiraz }\end{array}$ & $\begin{array}{l}\text { The success of surgery; correct diagnosis and prescription; right to } \\
\text { visit and medication costs; visa; residence; hospital and surgery costs; } \\
\text { visitation; operating room equipment; amenities }\end{array}$ & - & - \\
\hline Nikraftar et al ${ }^{66}$ & 2016 & $\begin{array}{l}\text { Cross-sectional } \\
\text { survey }\end{array}$ & Shiraz & Regulation & Providing services and human resources & $\begin{array}{l}\text { Policies needed to improve quality; adherence to } \\
\text { international standards }\end{array}$ \\
\hline Hajinejad et al ${ }^{67}$ & 2016 & $\begin{array}{l}\text { Cross-sectional } \\
\text { qualitative }\end{array}$ & Mashhad & Different infrastructure and specialties & $\begin{array}{l}\text { Establishing bilateral relations between the } \\
\text { countries of the region }\end{array}$ & Supporting the NGO sector; investment \\
\hline $\begin{array}{l}\text { Mosavi-negad } \\
\text { et a } \mathbf{l}^{68}\end{array}$ & 2016 & Cross-sectional & Tehran & $\begin{array}{l}\text { Diverse specialties; up-to-date equipment; minimum waiting times; } \\
\text { human and physical resources }\end{array}$ & Massive investment & - \\
\hline
\end{tabular}


Table 1. Continued

\begin{tabular}{|c|c|c|c|c|c|c|}
\hline \multirow{2}{*}{ Author } & \multirow{2}{*}{ Year } & \multirow{2}{*}{ Type of Research } & \multirow{2}{*}{$\begin{array}{l}\text { Place of } \\
\text { research }\end{array}$} & \multicolumn{3}{|c|}{ The Most Important Factors, Suggestions, and Programs for the Development of Medical Tourism in Iran } \\
\hline & & & & Factors & Suggestions & Programs \\
\hline Taghvaei et al ${ }^{69}$ & 2016 & $\begin{array}{l}\text { Cross-sectional } \\
\text { qualitative }\end{array}$ & Shiraz & - & $\begin{array}{l}\text { Increasing the quality and variety of } \\
\text { health services; electronic and non- } \\
\text { electronic advertising; cooperation with the } \\
\text { Islamic countries in the region; obtaining } \\
\text { international approvals; foreign language } \\
\text { training }\end{array}$ & - \\
\hline Azizi et a $\mathrm{l}^{00}$ & 2016 & $\begin{array}{l}\text { Cross-sectional } \\
\text { survey }\end{array}$ & Yazd & Costs; advertising; laws; medical needs; human resources & - & - \\
\hline Maleki et al ${ }^{71}$ & 2016 & $\begin{array}{l}\text { Cross-sectional } \\
\text { survey }\end{array}$ & Mashhad & $\begin{array}{l}\text { Information; electronic acceptance; financial exchange system; foreign } \\
\text { languages in hospital support; complete health tourism packages; visa; } \\
\text { inland transportation }\end{array}$ & - & - \\
\hline Maboodi et a $\mathrm{l}^{72}$ & 2016 & $\begin{array}{l}\text { Cross-sectional } \\
\text { survey }\end{array}$ & $\begin{array}{l}\text { Whole country } \\
\text { (Iran) }\end{array}$ & Cost of medical services; quality; human resources; medical equipment & - & - \\
\hline Anabestani et al ${ }^{73}$ & 2016 & $\begin{array}{l}\text { Cross-sectional } \\
\text { survey }\end{array}$ & Mashhad & Quality of health services; information; interagency coordination & $\begin{array}{l}\text { Construction of medical tourism services } \\
\text { companies }\end{array}$ & - \\
\hline Nemati et al ${ }^{59}$ & 2016 & $\begin{array}{l}\text { Cross-sectional } \\
\text { survey }\end{array}$ & Ardabil & Quality of service; human resources & - & $\begin{array}{l}\text { Information and marketing systems; policymaking and } \\
\text { legislation; infrastructure }\end{array}$ \\
\hline $\begin{array}{l}\text { Mahmoudifar } \\
\text { et al }{ }^{74}\end{array}$ & 2016 & $\begin{array}{l}\text { Cross-sectional } \\
\text { survey }\end{array}$ & West Azerbaijan & - & Coordination of effective organizations & Decision-making and planning departments \\
\hline Rezaee et al ${ }^{75}$ & 2016 & $\begin{array}{l}\text { Qualitative } \\
\text { survey }\end{array}$ & $\begin{array}{l}\text { Whole country } \\
\text { (Iran) }\end{array}$ & Quality of service; highly specialized services; cost; proper equipment & - & A comprehensive and coherent program of medical tourism \\
\hline Faridi masuleh ${ }^{76}$ & 2017 & Qualitative & $\begin{array}{l}\text { Whole country } \\
\text { (Iran) }\end{array}$ & - & Supporting private investment & - \\
\hline Jabbari et al77 & 2017 & Cross-sectional & Shiraz & - & - & More advertising of hospitals' quality of services \\
\hline $\begin{array}{l}\text { Abouhashem } \\
\text { Abadi et al }{ }^{78}\end{array}$ & 2017 & $\begin{array}{l}\text { Descriptive; } \\
\text { exploratory }\end{array}$ & Yazd & - & $\begin{array}{l}\text { Construction of medical tourism companies } \\
\text { or encouragement of private sector } \\
\text { investment; Preparation of various programs; } \\
\text { Addressing issues related to medical } \\
\text { tourism; Developing medical tourism service } \\
\text { standards by specialized firms providing } \\
\text { tourism services; creating an extensive } \\
\text { network of marketing and sales }\end{array}$ & $\begin{array}{l}\text { Training staff related to foreign patients by international } \\
\text { approvals }\end{array}$ \\
\hline Azimi et $\mathrm{al}^{79}$ & 2017 & Cross-sectional & Mashhad & - & $\begin{array}{l}\text { It is suggested that advertising practices } \\
\text { be revised and novel methods adopted to } \\
\text { appeal to a greater range of potential tourists. }\end{array}$ & $\begin{array}{l}\text { Senior executives of hospitals are recommended to account } \\
\text { for the safety, comfort, and well-being of patients as basic } \\
\text { requirements of marketing. }\end{array}$ \\
\hline $\begin{array}{l}\text { Haji Ahmadi et } \\
\text { alo }^{80}\end{array}$ & 2017 & Qualitative & $\begin{array}{l}\text { Whole country } \\
\text { (Iran) }\end{array}$ & Marketing of medical tourism; having a relative competitive advantage & $\begin{array}{l}\text { Service and welfare factors; advertising } \\
\text { factors; physical factors; political and } \\
\text { geographical factors; human factors. }\end{array}$ & - \\
\hline
\end{tabular}




\section{Table 1. Continued}

\begin{tabular}{|c|c|c|c|c|c|c|}
\hline \multirow{2}{*}{ Author } & \multirow{2}{*}{ Year } & \multirow{2}{*}{ Type of Research } & \multirow{2}{*}{$\begin{array}{l}\text { Place of } \\
\text { research }\end{array}$} & \multicolumn{3}{|c|}{ The Most Important Factors, Suggestions, and Programs for the Development of Medical Tourism in Iran } \\
\hline & & & & Factors & Suggestions & Programs \\
\hline Azimi et a $\mathrm{l}^{81}$ & 2017 & Descriptive & Mashhad & Services; place; promotion; price; people; process; facilities & $\begin{array}{l}\text { It is necessary to pay further attention to } \\
\text { the adoption of appropriate strategies to } \\
\text { recruit skilled people, provide services based } \\
\text { on international standards, and change } \\
\text { processes in hospitals. }\end{array}$ & $\begin{array}{l}\text { Promote competition; adopting new advertising media such } \\
\text { as websites and mass media; special attention paid to the } \\
\text { revision of fee. }\end{array}$ \\
\hline $\begin{array}{l}\text { RahimiZarchi } \\
\text { et al }\left.\right|^{82}\end{array}$ & 2017 & Qualitative & Shiraz & $\begin{array}{l}\text { Cost; advertisements; good weather and nature; cultural and historical } \\
\text { attractions; famous doctors; equipment and facilities; advanced and up- } \\
\text { to-date therapies }\end{array}$ & - & - \\
\hline Najafi et al ${ }^{84}$ & 2017 & Review & $\begin{array}{l}\text { Whole country } \\
\text { (Iran) }\end{array}$ & $\begin{array}{l}\text { Medical costs; quality of medical services; service coverage; medical } \\
\text { staff; Health system infrastructure, accommodations; travel arrangements; } \\
\text { marketing; tourist attractions; economic situation of countries; social } \\
\text { background of countries; security; managers' commitment }\end{array}$ & - & - \\
\hline Danial et a $\left.\right|^{85}$ & 2017 & $\begin{array}{l}\text { Review and } \\
\text { qualitative }\end{array}$ & $\begin{array}{l}\text { Whole country } \\
\text { (Iran) }\end{array}$ & The importance of training in medical tourism & $\begin{array}{l}\text { Provision of equipment and necessary } \\
\text { training, including an introduction to } \\
\text { medical tourism and the medical tourist; } \\
\text { the medical histories of medical tourists; the } \\
\text { association of staff with medical tourism }\end{array}$ & - \\
\hline $\begin{array}{l}\text { Najafi Nasab } \\
\text { et al }{ }^{86}\end{array}$ & 2018 & Survey & $\begin{array}{l}\text { Whole country } \\
\text { (Iran) }\end{array}$ & $\begin{array}{l}\text { Policies; advertising and marketing; the capacities of medical and } \\
\text { healthcare services; costs; destination characteristics }\end{array}$ & - & $\begin{array}{l}\text { The Ministry of Health and Medical Education, the Iranian } \\
\text { Cultural Heritage and Tourism Organization, and the } \\
\text { Medical Council of the Ministry of Foreign Affairs should } \\
\text { make appropriate policies to stimulate the entry of foreign } \\
\text { medical tourists to the country. }\end{array}$ \\
\hline Momeni et a ${ }^{87}$ & 2018 & Qualitative & $\begin{array}{l}\text { East } \\
\text { Azerbaijan }\end{array}$ & $\begin{array}{l}\text { Marketing; international issues; culture; transfer; brokerage; management } \\
\text { and policy problems }\end{array}$ & $\begin{array}{l}\text { Provision of the necessary context for the } \\
\text { participation and investment of the private } \\
\text { sector in the field of medical tourism. }\end{array}$ & - \\
\hline Sadeh et a $\mathrm{l}^{88}$ & 2018 & $\begin{array}{l}\text { Descriptive- } \\
\text { survey }\end{array}$ & - & $\begin{array}{l}\text { Physical environment and convenience; pharmaceutical services; } \\
\text { treatment services from the medical team; technical care competencies; } \\
\text { costs; hospitality services }\end{array}$ & - & - \\
\hline $\begin{array}{l}\text { Asgarnezhad } \\
\text { Nouri et al }{ }^{89}\end{array}$ & 2018 & $\begin{array}{l}\text { Descriptive and } \\
\text { correlational }\end{array}$ & Ardabil & Enjoyment; costs; risk effects & - & $\begin{array}{l}\text { Provision of standard services; building appropriate } \\
\text { infrastructure for medical tourists to create a positive image }\end{array}$ \\
\hline Ebrahimi et a ${ }^{90}$ & 2018 & $\begin{array}{l}\text { Descriptive- } \\
\text { survey }\end{array}$ & Tehran & - & - & $\begin{array}{l}\text { Providing a regular and well-designed program for medical } \\
\text { tourists to know and plan properly }\end{array}$ \\
\hline Hoseinpour et al ${ }^{91}$ & 2018 & $\begin{array}{l}\text { Descriptive- } \\
\text { analytical }\end{array}$ & Ardebil & Country status; condition of hospitals; medical team; mineral spas & $\begin{array}{l}\text { The authorities in the field of health and } \\
\text { tourism help more in the development of } \\
\text { this industry by providing the necessary } \\
\text { substructures of this sector and execution of } \\
\text { macro politics. }\end{array}$ & - \\
\hline
\end{tabular}


as influencing factors in attracting medical tourism. Most articles cite advertising, marketing, and updated medical procedures as planning for these factors.

\section{Discussion}

The present study attempted to find a set of strategies and programs for the development of medical tourism in hospitals affiliated with the Shiraz University of Medical Sciences. Based on the present findings, important factors such as policymaking, coherent planning, and informing about capabilities and capacities through appropriate information channels will play an important role in the development of medical tourism. In general, information plays an important role in attracting medical tourists. Hospitals and medical centers, insurance companies, tours, intermediaries, and settlement centers play important roles in providing information. In other words, there should be a network of communication between various institutions in medical tourism, and the information and marketing method should be coordinated based on the cooperation of these institutions. The proper information process attracts tourists. Azimi et $\mathrm{al}^{81}$ and Alizadehsani ${ }^{92}$ pointed to the role of advertising and information on the development of medical tourism in their research and suggested that countries must develop a regular system of marketing and information activities to be successful in tourism. In studies conducted by Rokni et $\mathrm{al}^{41}$ Jabbari et $a l,{ }^{43}$ Goodarzi et $a l,{ }^{46}$ Ayoubian et $a l,{ }^{51}$ and Taghi Zadeh Namen et al, ${ }^{52}$ effective advertising was reported as one of the important factors in attracting medical tourists.

Viladrich and Baron-Faust's ${ }^{93}$ research in Argentina showed that internet marketing has made the country a hub of cosmetic surgeries. In studies conducted by Momeni et al. ${ }^{87}$ Najafi Nasab et $\mathrm{al}^{86}$ and Haji Ahmadi et $\mathrm{al}^{80}$ marketing was mentioned as one of the effective factors in attracting medical tourists. Yang ${ }^{94}$ also conducted a study on the factors influencing medical tourism marketing from the perspective of practitioners in this field, including tourism agencies and medical institutions in Taiwan, which showed that among the 15 factors studied, branding was the first priority; factors regarding medical facilities and the quality of medical services were also top priorities.

Zuhri et $\mathrm{al}^{95}$ concluded that the perceived quality of medical services and their perceptual value, trust, mental image, and competitiveness can directly influence the choice of destination and tourists' loyalty.

In addition to these factors, there are the physical and infrastructural factors in research that are undeniable necessities for medical tourism. The quality of a country's infrastructure is one of the most important factors contributing to the development of medical tourism. In studies conducted by Sadr Momtaz et al, ${ }^{25}$ Mahmoudifar et al, ${ }^{74}$ Naami et al, ${ }^{83}$ Najafi et al, ${ }^{84}$ and Asgarnezhad Nouri et al, ${ }^{89}$ infrastructure is mentioned as one of the factors effective in attracting medical tourists.

In studies conducted by Sadeh et al, ${ }^{88}$ Najafi Nasab et al, ${ }^{86}$ and Bishami et $\mathrm{al}^{58}$ cost is one of the effective factors in attracting medical tourists.
Review Highlights

What Is Already Known?

In Iran, little attention is paid to medical tourism. Identification and planning factors based on the priorities specified in the field of medical tourism are very important.

\section{What This Study Adds?}

Strategies offered by various managers and authorities in tourism can lead to the increased attraction of medical tourists to public and private hospitals in Shiraz, relying on the capabilities and potential of Shiraz, and thereby generating more foreign exchange earnings and employment.

\section{Conclusion}

Today, medical tourism in the world is a developing industry with a significant turnover. Iran has the potential to make the most of this opportunity. Strategies offered by various managers and authorities in tourism can lead to increased attraction of medical tourists to public and private hospitals in Shiraz, relying on capabilities and potential of Shiraz and its health sectors, including climate and nature, cultural and historical attractions, renowned practitioners, advanced equipment, facilities, and methods. Thereby, more foreign exchange earnings and employment will be generated.

\section{Authors' Contributions}

MG: Conceptualization, writing, reviewing, and editing the manuscript; supervision. AMKHA: Conceptualization, writing the original draft of the article, writing, reviewing, and editing the manuscript; supervision. SM: Writing, reviewing, and editing the manuscript. MG: Writing, reviewing, and editing the manuscript.

\section{Conflict of Interest Disclosures}

The authors have no conflicts of interest.

\section{Ethical Approval}

Not applicable.

\section{Funding/Support}

None.

\section{Acknowledgments}

The authors would like to thank Shiraz University of Medical Sciences, Shiraz, Iran, the Center for Development of Clinical Research of Nemazee Hospital, and Dr. Nasrin Shokrpour for her editorial assistance.

\section{Reference}

1. Baker DM. Medical tourism development, challenges and opportunities for Asia. Almatourism-Journal of Tourism, Culture and Territorial Development. 2015;6(12):193-210. doi:10.6092/ issn.2036-5195/5315.

2. Smith MK, Puczkó L. Health, Tourism and Hospitality: Spas, Wellness and Medical Travel. London: Routledge; 2014.

3. Ramirez de Arellano AB. Patients without borders: the emergence 
of medical tourism. Int J Health Serv. 2007;37(1):193-198. doi:10.2190/4857-468g-2325-47uu.

4. Sheikholeslami N, Rezaeian M, Bahsoun M, Taghavipoor M. Medical tourism: the view of Rafsanjan Medical University staff. Iranian Journal of Epidemiology. 2010;5(4):31-36.

5. Williams D, Seus J. Medical tourism: implications for participants in the US health care system. Retrieved January. 2007;15:2013.

6. Khan MJ, Chelliah S, Haron MS. Medical tourism destination image formation process: a conceptual model. Int J Healthc Manag. 2016;9(2):134-143. doi:10.1080/20479700.2016.11420 46.

7. Esiyok B, Çakar M, Kurtulmuşoğlu FB. The effect of cultural distance on medical tourism. J Dest Mark Manage. 2017;6(1):6675. doi:10.1016/j.jdmm.2016.03.001.

8. Cohen ECE. Medical tourism in Thailand. AU-GSB e-journal. 2008;1(1):24-37.

9. Hay B. From a Medical Tourism Hospital to a National Health Service Hospitak in Eight Easy Years! A Case Study of the Golden Jubilee Hospital in Glasgow, Scotland. Queen Margaret University; 2010.

10. Horowitz MD, Rosensweig JA, Jones CA. Medical tourism: globalization of the healthcare marketplace. MedGenMed. 2007;9(4):33.

11. Al Khaja KA, Sequeira RP, Damanhori AH. Polypharmacy associated with medical tourism: a critique on drug therapy. Int J Clin Pharm. 2011;33(1):61-65. doi:10.1007/s11096-010-9477-7.

12. Hopkins L, Labonté R, Runnels V, Packer C. Medical tourism today: what is the state of existing knowledge? J Public Health Policy. 2010;31(2):185-198. doi:10.1057/jphp.2010.10.

13. Bauer JC. Medical tourism: wave of the future in a world of hurt? Healthc Financ Manage. 2009;63(8):36-38, 40, 42.

14. Courtney L, Valverde L. Potential Impacts of Medical Tourism on Health Care in Costa Rica. Costa Rica: Instituto de Investigaciones Sociales, Universidad de Costa Rica; 2010:1-10.

15. Unti JA. Medical and surgical tourism: the new world of health care globalization and what it means for the practicing surgeon. Bull Am Coll Surg. 2009;94(4):18-25.

16. Delgoshaei B, Ravaghi H, Abolhassani N. Importance-Performance analysis of medical tourism in Tehran province from medical tourists and medical services providers' perspective. Hospital. 2012;11(1):63-72. [Persian].

17. Rahimipour A. Statistical analysis of the world tourism industry, future markets and the position of Iran. Journal of Tourism. 2012;1(1):1-18. [Persian].

18. Kazemi Z. Study of the Effective Factors for Attracting Medical Tourism in Iran. Luleå University of Technology; 2008.

19. Zia Sheikholeslami N, Rezaeian M, Bahsoun M, Taghavipoor M. Medical tourism: the view of Rafsanjan medical university staff. Iran J Epidemiol. 2010;5(4):31-36. [Persian].

20. Tourani S, Tabibi SJ, Tofighi SH, Shaarbafchi Zadeh N. Medical tourism in Iran: analysis of opportunities and challenges with MADM approach. Res J Biol Sci. 2010;5(3):251-257. doi:10.3923/ rjbsci.2010.251.257.

21. Jafari H, Bakhtiari E, Keshtkar M. Medical Tourism and its Importance in Iran Health System. The First International Conference on Tourism Management and Sustainable Development. Fars, Iran: Islamic Azad University Marvdasht Branch; 2011.

22. Moghimehfar F, Nasr-Esfahani MH. Decisive factors in medical tourism destination choice: a case study of Isfahan, Iran and fertility treatments. Tour Manag. 2011;32(6):1431-1434. doi:10.1016/j. tourman.2011.01.005.

23. Khodayari R, Tourani S, Qaderi A, Salehi M, Jafari H. Capabilities assessing of teaching hospitals in Iran university of medical sciences in attracting medical tourists according to $\mathrm{JCl}$ patientoriented standards. Hospital. 2011;9(3):51-56. [Persian].

24. Nasiripour AA, Salmani L. The role of Tehran's hospitals capability in development of medical tourism. Hospital. 2011;9(3):57-68. [Persian].
25. Sadr Momtaz N, Agharahimi Z. Medical tourism industry in Iran: strategies for development. Health Inf Manag. 2011;7:516-524. [Persian].

26. Izadi M, Saadat SH, Ayoubian A, Dehaghi ZH, Karbasi MR, Jalali AR. Health tourism in Iran; identifying obstacles for development of this industry. Int J Travel Med Glob Health 2013;1(2):89-94.

27. Ferdosi M, Jabbari A, Keyvanara M, Agharahimi Z. A systematic review of publications studies on medical tourism. J Educ Health Promot. 2013;2:51. doi:10.4103/2277-9531.119037.

28. Jabbari A, Delgoshaei B, Mardani R, Tabibi SJ. Medical tourism in Iran: Issues and challenges. J Educ Health Promot. 2012;1:39. doi:10.4103/2277-9531.104809.

29. Zia Sheikholeslami N, Bahsoun M, Zia Sheikholeslami N S. Medical tourism in Iran: attitude and challenges. Electron Physician. 2012;4(2):511-515.

30. Jabbari A, Agharahimi Z, Seid Moradi Z, Ferdosi M. Potentials of cosmetic surgery tourism in Isfahan: a qualitative study. Health Inf Manag. 2012;9(5):686-696. [Persian].

31. Tabibi SJ, Nasiripour AA, Ayoubian A, Bagherian Mahmoodabadi $\mathrm{H}$. The relation between information mechanisms and medical tourist attraction in hospitals of Tehran, Iran. Health Inf Manag. 2012;9(3):416-423. [Persian].

32. Shaarbafchi Zadeh N, Azami S, Bastani P. Opportunities and challenges against cross border supply of health services in Iranian health sector: a qualitative approach. Razi Journal of Medical Sciences. 2012;19(100):1-11. [Persian].

33. Izadi M, Ayoubian A, Nasiri T, Joneidi N, Fazel M, Hosseinpourfard MJ. Situation of health tourism in Iran opportunity or threat. Journal of Military Medicine. 2012;14(2):69-75. [Persian].

34. Delgoshaie B, Jabbari A, Farzin M, Shaarbafchi Zadeh N, Tabibi SJ. Current medical tourism in Iran: a case study. Payesh. 2012;11(2):171-179. [Persian].

35. Arabshahi Korizi A, Arianfar M. Health tourism and medical tourism capabilities in Iran. Geographical Journal of Tourism Space. 2014;3(9):133-152. [Persian].

36. Hadizadeh Moghadam A, Zahediannejad M, Ghanbarzadeh Miyandehi R, Fakharmanesh S. Pattern of factors affecting the motivation of medical tourists to enter Iran. Management Perspective. 2013;12(3):59-79. [Persian].

37. Mehrjerdi YZ, Faregh F. Modeling medical tourism in Iran using the system dynamic approach. Iranian Journal of Management Sciences. 2013;8(31):105-130. [Persian].

38. Keshavarz H, Jabarifar SE, Hosseinpour K. Evaluation of social, cultural and infrastructural factors influencing the development of dental tourism in Isfahan, Iran. Journal of Isfahan Dental School. 2013;8(7):684-694. [Persian].

39. Jabbari A, Ferdosi M, Keyvanara M, Agharahimi Z. Stakeholders' analysis of the medical tourism industry: development strategies in Isfahan. J Educ Health Promot. 2013;2:44. doi:10.4103/22779531.117410.

40. Hajinejad A, Eslamfard F. Formulating strategies for the development of treatment tourism in Shiraz (Iran) using a strategic planning approach (SWOT). Journal of Rafsanjan University of Medical Sciences. 2013;12(8):641-654. [Persian].

41. Rokni L, Pourahmad A, Moteiey Langroudi MH, Rezaeiy Mahmoudi $M$, Heidarzadeh N. Appraisal the potential of central Iran, in the context of health tourism. Iran J Public Health. 2013;42(3):272279.

42. Mahdavi Y, Mardani S, Hashemidehaghi Z, Mardani N. The factors in development of health tourism in Iran. Int J Travel Med Glob Health. 2013;1(2):113-118.

43. Jabbari A, Rahimi Zarchi MK, Kavosi Z, Shafaghat T, Keshtkaran A. The marketing mix and development of medical tourism in Shiraz. Mater Sociomed. 2013;25(1):32-36. doi:10.5455/ msm.2013.25.32-36.

44. Tabatabaeinasab SM, Nouri A, Mohammadnabi Z, Heshmati F. Customers' typology in medical tourism. Tourism Management Studies. 2015;9(26):60-82. [Persian]. 
45. Mesbahi SA, Janghorban Laricheh M, et al. Providing a Model for Designing Logical Data Structure of Therapeutic Tourism Information System as a Tool for Medical Tourism Development. Amirkabir University of Technology; 2014.

46. Goodarzi M, Taghvaei M, Zangiabadi A. Factor analysis of effective factors on the improvement of medical tourism in shiraz megalopolis. Environmental Management and Sustainable Development. 2014;3(1):138-151. doi:10.5296/emsd.v3i1.4876.

47. Noori Hekmat S, Jabbari A, Dehnavieh R, Mardani R. Readiness of hospitals to infare medical tourism industry: Isfahan city. Health Inf Manag. 2014;11(4):506-516. [Persian].

48. Goodarzi M, Taghvaei M, Zangiabadi A. Developing of domestic medical tourism in Shiraz. Health Inf Manag. 2014;11(4):485-496. [Persian].

49. Goodarzi M, Taghvaei M, Zangiabadi A. Investigation and evaluation of the impacting factors on the development of medical tourism in Shiraz megalopolis. Tourism Management Studies. 2014;8(23):1-25. [Persian].

50. Mir M, Tajzadehnamin AA. Assessing preparation level of medical tourism in Zahedan. Global Journal of Management and Business Research. 2014;14(1):26-34.

51. Ayoubian A, Tourani S, Hashemidehaghi Z. Medical tourism attraction of Tehran hospitals. Int J Travel Med Glob Health. 2013;1(2):95-98.

52. Tajzadeh-Namin A, Bayat S. The study of the effectiveness of medical tourism websites in Iran. Tourism Management Studies. 2015;10(30):53-75. [Persian].

53. Safaeepur M, Tavangar M. Analysis of the health tourism marketing management in Iran. J Appl Environ Biol Sci. 2015;5(10S):780786.

54. Hosseini SM, Mohammadzadeh KA, Zahraei Bakhsh F, Nabian MH. Medical tourists' perception of service quality in children's medical center of Tehran, Iran. J Orthop Spine Trauma. 2016;2(3):e11195. doi:10.5812/jost.11195.

55. Karami F, Bayati Khatibi M, Talebzadeh Shoushtari A. Determining and prioritizing factors affecting the development of medical tourism with an emphasis on domestic tourists (case study: city of Mashhad). Journal of Geography and Regional Development. 2017;14(2):109-128.

56. Lajevardi M. A comprehensive perspective on medical tourism context and create a conceptual framework. Journal of Tourism \& Hospitality. 2016;5(5):236. doi:10.4172/2167-0269.1000236.

57. Mahmoudifar Y, Tabibi SJ, Nasiripour AA, Riahi L. Factors affecting development of medical tourism industry in west Azerbaijan province of Iran. Int J Health Stud. 2016;2(4):25-31. doi:10.22100/ ijhs.v2i4.181.

58. Bishmi B, Varmazyar A. Medical tourism capabilities in Iran and ranking the capabilities using analytical hierarchy process. Heritage and Tourism Journal. 2016;1(2):93-108. [Persian].

59. Nemati V, Ebrahimpour H, Babaee $\mathrm{Y}$, Abbasgholizadeh N. Assessing barriers to the development of medical tourism case study: Ardabil. Journal of Health. 2016;7(2):118-133. [Persian].

60. Ranjnoush R, Zargham Boroujeni H, Hamidi N. Segmentation of medical tourism business in Iran: from foreign patients point of view. Journal of Tourism Planning and Development. 2016;5(18):54-72. [Persian].

61. Mirbolouk Z, Khodadad Hosseini SH, Hematinejad MA, Noorsalehi E. Designing the medical tourism trends model in Guilan province, Iran. Health Inf Manag. 2016;13(3):29-215. [Persian].

62. Samadbeik M, Asadi H, Mohseni M, Takbiri A, Moosavi A, Garavand A. Designing a medical tourism website: a qualitative study. Iran J Public Health. 2017;46(2):249-257.

63. Abouhashem Abadi F. The components and contents of medical tourism facilitator websites. Tourism Management Studies. 2016;11(33):1-18. [Persian].

64. Badei F, Ebrahimi A, Dideh Khani H. Medical tourism development in Golestan province, an assessment of identified solutions. New
Marketing Research Journal. 2016;6(4):25-36. [Persian].

65. Hamidizadeh M, Javidi H, Mojarrad F. Iran's competitive advantage in medical tourism marketing: a case study on open heart and cataract removal surgeries. Health Inf Manag. 2016;13(5):373379. [Persian].

66. Nikraftar T, Hosseini E, Moghadam A. Identify policy implications of medical tourism in Iran. Public Policy. 2016;2(2):141-156. [Persian].

67. Hajinejad A, Anabestani A, Safarian M. Strategic planning of medical tourism with an emphasis on religious tourism in Mashhad city. Geographical Researches Quarterly Journal. 2016;31(2):101114. [Persian].

68. Mosavi-negad SM, Adeli O, Hariri T, Vali-pour N, Moshkani Z. The potential of medical tourist's attraction in hospitals (a case study of a military hospitals in Tehran). Hospital. 2016;15(3):63-71. [Persian].

69. Taghvaei M, Goodarzi M. Developing and prioritizing the formation of strategies in medical tourism (case study: Shiraz metropolis). Research and Urban Planning. 2016;7(24):1-22. [Persian].

70. Azizi F, Zahedi SH. Assessment of the barriers to the development of health tourism in Yazd province, Iran. Health Inf Manag. 2016;12(6):799-806. [Persian].

71. Maleki S, Tavangar M. Analyzing health tourism challenges in Mashhad from the perspective of foreign patients. Journal of Geography and Urban Space Development. 2016;2(2):153-165. doi:10.22067/gusd.v2i2.40771. [Persian].

72. Maboodi MT, Hakimi H. Determinant factors on medical tourism (case study: Iran). Journal of Tourism Planning and Development. 2016;4(15):80-106. [Persian].

73. Anabestani A, Anabestani Z. Factors affecting the choice of Mashhad as objective medical tourism. Journal of Urban Tourism. 2015;2(3):275-289. [Persian].

74. Mahmoudifar Y, Tabibi SJ, Nasiripour AA, Riahi L. Effective factors on the development of medical tourism industry in the west Azerbaijan province, Iran: pattern presentation. Int J Med Res Health Sci. 2016;5(7S):620-630.

75. Rezaee R, Mohammadzadeh M. Effective factors in expansion of medical tourism in Iran. Med J Islam Repub Iran. 2016;30:409.

76. Faridi Masuleh A. Rating the medical and health facilities of the country's provinces for medical tourism. Heritage and Tourism Journal. 2017;2(7):13-37. [Persian].

77. Jabbari A, Gholami M, Kavosi Z, Chamanpara P, Gholami M. Potential factors affecting medical tourists' viewpoint about healthcare services quality in Shiraz, Iran. Int J Hosp Res. 2017;6(2):85-89.

78. Abouhashem Abadi F, Ghasemian Sahebi I, Arab A, Alavi A, Karachi $\mathrm{H}$. Application of best-worst method in evaluation of medical tourism development strategy. Decis Sci Lett. 2018;7(1):77-86. doi:10.5267/j.dsl.2017.4.002.

79. Azimi R, Mahmoudi G, Esmaeili HA. Ranking factors affecting the attraction of foreign medical tourists in hospitals affiliated to Mashhad university of medical sciences based on marketing mix model. Iran J Public Health. 2018;47(10):1593-1598.

80. Haji Ahmadi S, Hosseini SM, Jafari M. Factors affecting the attraction of medical tourists in Iran. Int J Med Rev. 2017;4(2):4751. doi:10.29252/ijmr-040204.

81. Azimi R, Mahmoudi G, Esmaeili HA. A study of the effect of advertising on attracting medical tourism. Int J Travel Med Glob Health. 2017;5(3):89-93. doi:10.15171/ijtmgh.2017.19.

82. Rahimi Zarchi MK, Shafaghat T, Hatam N. Shiraz medical tourism industry: development strategies. Management Strategies in Health System. 2017;2(2):88-95. [Persian].

83. Naami A, Chatrooz A. Systematic review of medical tourism in Iran and case study of Tehran university of medical sciences. Journal of Payavard Salamat. 2018;11(5):598-609. [Persian].

84. Najafi B, Raeissi P, Gorji HA, Ahmadi A, Haghighi M. Identifying factors affecting destination choice of medical tourists: a systematic 
review of literature. J Fundam Appl Sci. 2017;9(2S):1309-1328. doi:10.4314/jfas.v9i2s.846.

85. Danial Z, Abbaspour A, Rahimian H, Shaarbafchi Zadeh N, Niknami M. Training for medical tourism in Iran. Int J Travel Med Glob Health. 2017;5(3):77-83. doi:10.15171/ijtmgh.2017.17.

86. Najafi Nasab M, Agheli L, Andrade MV, Sadeghi H, Faraji Dizaji $\mathrm{S}$. Determinants of medical tourism expansion in Iran: structural equation modeling approach. Iran J Econ Stud. 2018;7(2):169189. doi:10.22099/ijes.2018.30739.1485.

87. Momeni K, Janati A, Imani A, Khodayari-Zarnaq R. Barriers to the development of medical tourism in East Azerbaijan province, Iran: a qualitative study. Tour Manag. 2018;69:307-316. doi:10.1016/j. tourman.2018.05.007.

88. Sadeh E, Garkaz M. Interpretive structural modeling of quality factors in both medical and hospitality services in the medical tourism industry. J Travel Tour Mark. 2019;36(2):253-267. doi:10 .1080/10548408.2018.1527273.

89. Asgarnezhad Nouri B, Nemati V, Abbasgholizadeh N. The effect of perceived value on the destination image, satisfaction and loyalty of medical tourists: a case study in Ardabil. Journal of Health. 2019;10(1):34-49. doi:10.29252/j.health.10.1.34. [Persian].

90. Ebrahimi M, Tayebi-Abolhasani SA, Rostami M. Medical tourism market in selected hospitals in Tehran city, Iran: application of clustering. Health Inf Manag. 2018;15(3):114-119. doi:10.22122/ him.v15i3.3572. [Persian].

91. Hoseinpour R, Riyahi L. Relationship between medical therapy tourism and the rate of tourism attraction in Ardabil province. Journal of Health. 2018;9(2):159-171. doi:10.29252/j. health.9.2.159. [Persian].

92. Alizadehsani M, Farahani B, Ahmadikhatir T. Wellness tourism motivational factors in hot springs of Mazandaran province: the case of Ramsar and Lavij hot springs. Journal of Tourism Planning and Development. 2015;3(11):33-52. [Persian].

93. Viladrich A, Baron-Faust R. Medical tourism in tango paradise: the internet branding of cosmetic surgery in Argentina. Ann Tour Res. 2014;45:116-131. doi:10.1016/j.annals.2013.12.007.

94. Yang YS. Key success factors in medical tourism marketing. Int J Acad Res Bus Soc Sci. 2013;3(3):152-158.

95. Zuhri S, Ilyas S, Sentia PD. The Analysis of Relationships Among Variables Toward Medical Tourism to Malaysia by Employing Structural Equation Modelling. Banda Aceh, Indonesia: International Conference on Engineering and Science for Research and Development (ICESReD); 2016:167-175. 